\title{
STEPS TO IMPROVE LOGBOOK COMPLIANCE FOR DIESEL REBATES: A PROCESS-DRIVEN APPROACH
}

\author{
S.R. Ngwaku ${ }^{1 *}$, J. Pascoe ${ }^{1}$, J.C. Vosloo \& J.H. van Laar $^{2}$
}

\section{ARTICLE INFO}

Article details

Presented at the $32^{\text {nd }}$ annual conference of the Southern African Institute for Industrial Engineering (SAIIE), held from 4-6 October 2021 in Muldersdrift, South Africa.

Available online $\quad 29$ Nov 2021

Contact details

Corresponding author Refilwe.ngwaku@gmail.com

Author affiliations

1 Centre for Research and Continued Engineering Development, North West University, South Africa

2 Department of Industrial Engineering, Stellenbosch University, South Africa

\section{ORCID® identifiers}

S.R. Ngwaku

https://orcid.org/0000-0002-3226-6941

J. Pascoe

https://orcid.org/0000-0001-7137-2678

J.C. Vosloo

https://orcid.org/0000-0003-1063-0252

J.H. van Laar

https://orcid.org/0000-0003-0457-328X

DOI

http://dx.doi.org/10.7166/32-3-2624
ABSTRACT

Diesel accounts for up to 46 per cent of mining operations costs. In 2001, the Customs and Excise Act was amended to allow rebates for qualifying diesel users. The rebate aims to protect the international competitiveness of the South African mining industry. One of the key requirements for the diesel rebate is to submit logbooks that are compliant; however, the mining industry is struggling to maintain accurate logbook verification. Failure to comply with logbook requirements has prevented eligible mines from benefitting from the rebate. This paper presents a stepwise methodology to support the values reported in logbooks and submitted to the South African Revenue Service (SARS). The methodology focuses on four issues of data quality: data measurement, data verification, data traceability, and data reporting. With this approach, 151 errors were identified and corrected in a case study. A compliant logbook is shown to be the first step towards improved diesel management.

\section{OPSOMMING}

Dieselverbruik is verantwoordelik vir tot 46 persent van mynboubedryfskoste. Die Wet op Doeane en Aksyns is in 2001 gewysig om kortings toe te laat vir sommige dieselverbruikers. Die korting se doel is om die internasionale mededingendheid van die Suid-Afrikaanse mynboubedryf te beskerm. Een van die sleutel vereistes vir die dieselkorting is die indien van logboeke wat aan die vereistes voldoen. Die mynboubedryf sukkel egter om akkurate logboekverifikasie te handhaaf. Versuim om aan die logboekvereistes te voldoen verhoed myne wat vir die korting in aanmerking kom om daaruit voordeel te trek. Hierdie artikel bied ' $\mathrm{n}$ stapsgewyse metodologie om logboeke wat by die Suid-Afrikaanse Inkomste Diens ingedien is te ondersteun. Die metodologie fokus op vier kwessies van data gehalte, naamlik data meting, data verifikasie, data naspeurbaarheid en data rapportering. Deur hierdie benadering is 151 foute identifiseer en reggestel tydens 'n gevallestudie. 'n Logboek wat aan die vereistes voldoen is die eerste stap tot verbeterde dieselbestuur.

\section{BACKGROUND}

\subsection{The South African energy environment}

South Africa (SA) is an energy-intensive country, with the main energy sources being coal, diesel, and natural gas [1]. The majority of South Africa's energy is consumed by various industrial activities, including mining. In open-cast mining, fossil fuels (such as petroleum and diesel) are used to power the large vehicles that are used for loading and haulage [2],[3]. Such transport operations account for about 46 per cent of mining operational costs [2].

Mineral ore reserves are declining, forcing mining operations to mine much more deeply [4]. These actions are more energy-intensive, and place mines under increased financial pressure. Additionally, South African diesel prices are volatile and have increased considerably [5]. The South African government is aware of the financial pressure that the increase in fuel prices has placed on businesses, particularly primary producers such as the mining sector. 
In the light of the challenges faced by the mining industry, the South African government introduced the diesel rebate scheme in 2001 [5]. The aim of the scheme is to reduce the fuel tax burden embedded in the fuel price and to improve the international competitiveness of land-based primary producers (farming, forestry, and mining) [6].

\subsection{Overview of diesel rebate in SA}

The diesel rebate comprises two main elements: 100 per cent of the Road Accident Fund (RAF) levy, and 40 per cent of the general fuel levy (FL) [6]. From April 2021, the current diesel refund levy for the 'on land' primary sector has amounted to R3.66 per litre of eligible purchases. The diesel rebate system is governed by the Customs and Excise Act 91 of 1964 ('the Act') [7]; however, the refund is administered through the VAT system, which is subject to change.

Section 75 of the Act outlines the specific rebates and refunds on duties; but in respect of the diesel rebate, Schedule 6, Part 3 of the Act outlines in detail the conditions that should be met to qualify for that rebate [8]. The main requirements of the rebate are summarised in Table 1 below.

Table 1: Diesel rebate requirements according to the Act [7],[8]

\begin{tabular}{|l|l|c|}
\hline Requirements & & $\begin{array}{c}\text { Section in } \\
\text { document }\end{array}$ \\
\hline $\begin{array}{l}\text { Conduct eligible } \\
\text { activities }\end{array}$ & $\begin{array}{l}\text { In the context of mining, eligible activities include all activities carried out } \\
\text { solely for primary production (i.e., mining of metals, ore transportation and } \\
\text { collection, drilling, exploration, etc.) and exclude secondary activities to } \\
\text { process minerals (i.e., the refining of minerals and other activities post- } \\
\text { recovery). }\end{array}$ & $\begin{array}{c}\text { Schedule } 6 \text { Part } \\
3(6)(f)(i)(\text { aa) }\end{array}$ \\
\hline VAT registration & $\begin{array}{l}\text { Applicants will not be considered for the diesel rebate unless they are } \\
\text { registered for VAT; this means that small-scale organisations carrying } \\
\text { qualifying activities are exempt from the rebate. }\end{array}$ & $\begin{array}{c}\text { Schedule } 6 \text { Part } \\
3(6)(b)(c)(i i)\end{array}$ \\
\hline Record-keeping & $\begin{array}{l}\text { All books to substantiate the rebate claims must be kept for five years; these } \\
\text { records include purchase invoices, sales invoices, and logbooks. }\end{array}$ & $\begin{array}{c}\text { Schedule } 6 \text { Part } \\
3(6)(q)(i)(a a)\end{array}$ \\
\hline $\begin{array}{l}\text { Contractual } \\
\text { agreement }\end{array}$ & $\begin{array}{l}\text { In the event that eligible activities are carried out by a contractor, the } \\
\text { applicant must be able to prove that the contractor is employed on a dry } \\
\text { basis - i.e., they do not purchase their own diesel. }\end{array}$ & $\begin{array}{c}\text { Schedule } 6 \text { Part } \\
3(6)(e)(i)(b b)\end{array}$ \\
\hline
\end{tabular}

The diesel rebate exists for four main diesel usage types: on land (farming, mining, and forestry), offshore mining, electricity generation plants, and rail and harbour services. All four usage types are subject to different rebate rates [9]. However, the legislation only allows for 80 per cent of the eligible litres to be claimed [6],[7],[9]. The levy is presumed to increase annually, as it is an important source of revenue for the government [10].

\subsection{Diesel rebate calculation}

The diesel rebate system is based on the principle of self-assessment, and so places the duty to comply with the above-mentioned conditions solely on the claimant [11]. Using the information acquired from Schedule 6 of the Act, a formula for the diesel rebate claim can be derived. Equation 1 below is used to calculate the claimable rebate amount:

$$
C_{R}=E_{L} * 0.8 * R
$$

Here, $C_{R}$ is the claimable amount, $E_{L}$ represents the volume of eligible litres of diesel, and $R$ is the current diesel refund levy (rate). Legislation mandates that claims are supported by accurate and complete diesel logbooks that display the full diesel trail, from purchase to use. Two logbooks are required - the usage logbook and the storage logbook.

The total eligible litres of diesel $\left(E_{L}\right)$ is determined from the usage logbook and captured in the company's VAT return. Since the VAT system is nested under the South African Revenue Service (SARS), SARS is tasked by the legislation to audit the diesel rebate claims [7]. It is important to note that SARS can audit up to a five-year period after the rebate claim has been made.

\subsection{The challenges associated with the current diesel rebate system}

To evaluate the complexity of determining the $E_{L}$ value, an extensive literature study of available documentation on the diesel rebate was conducted. According to a review published by the National Treasury [6], a large number of participants, particularly those in the agricultural, forestry, and mining sectors, have been claiming refunds without maintaining logbooks. This is deemed unlawful and unethical. 
Agri SA, in collaboration with the South African Institute of Tax professionals (SAIT), conducted a survey with over 800 participants [12]. The survey concluded that complying with the requirements of the logbook is problematic and that there is still uncertainty regarding the auditing process. There have also been several court cases between the claimant and the commissioner of SARS pertaining to rebate conditions compliance [13].

Logbook compilation is dependent on accurate and representative data. However, data management in the mining sector is concerning, as data is not regarded as a valuable resource [14]. This creates a challenge in the diesel rebate process, as erroneous claims may result from the lack of an accurate and comprehensive data management system. From the Act, the main risks associated with the erroneous rebate claims are tabulated in

Table 2 below.

Table 2: Main risks on erroneous rebate claims according to the Act [7]

\begin{tabular}{|c|l|}
\hline ACT (Section) & \multicolumn{1}{c|}{ Risk } \\
\hline $75(1 \mathrm{~A}) \mathrm{d}$ & $\begin{array}{l}\text { (d) Any amount paid in error by the Commissioner of SARS to such person shall be recoverable } \\
\text { from such person as provided in section 76A. }\end{array}$ \\
\hline 75 (A1)e & $\begin{array}{l}\text { (e) The Commissioner may cancel the said registration of such person if such person claims or } \\
\text { receives any amount or payment to which he is not entitled. }\end{array}$ \\
\hline
\end{tabular}

The next section focuses on the challenges associated with calculating the total volume of eligible litres of diesel being used for rebates $\left(E_{L}\right.$ value). It is important that uncertainties are identified before they can be addressed [15].

\subsection{Identifying areas of uncertainty in the diesel rebate system}

Legislative uncertainty: Understanding the regulatory structure, and gaining knowledge of the rebate requirements, forms an integral part of any tax-related process [16]. In the context of the diesel rebate, the legislation states all the requirements needed for a compliant claim. These requirements are summarised in detail in Table 1 of Section 1, with the relative regulatory source and section.

Logbook compliance uncertainty: Quantification of the $E_{L}$ value can be difficult and time-consuming, and could contain erroneous values. This is because of the number of variables that are required, the volume of the data, and the calculation procedures. It is crucial to ensure that the $E_{L}$ value determined from logbooks is accurate and true. Knowing how to quantify this value gives stakeholders the confidence to take part in the diesel rebate scheme.

A formula is available to quantify the claimable amount $\left(C_{R}\right)$; however, there is no stepwise process for how $E_{L}$ is quantified and verified. SARS has published a template of the logbooks required [17], but it is specifically for farming. There are no clear instructions from SARS on how the logbook should be compiled and what is meant by a 'detailed and accurate' logbook.

Reporting uncertainty: The diesel rebate is reported on the VAT system as part of the monthly VAT return to SARS. The $E_{L}$ value is currently being reported without any supporting documents to substantiate the claim. This poses a risk to stakeholders and the government.

Assurance uncertainty: 'Assurance' is defined as certainty - i.e., being certain that the value reported is a true representation of the system [15]. The $E_{L}$ value is a self-assessed value that includes a multifaceted calculation process. Ensuring that this value is correct and accurate is important for stakeholder confidence. The penalties associated with incorrectly reported values are listed in

Table 2.

It is evident that the biggest challenge is quantifying the $E_{L}$ value from the logbook and ensuring that the value is correct and accurate. In order to help to assure stakeholder confidence, guidance is required for the areas of uncertainty. However, limited guidance is provided in the Act and the supplementary regulations. No method is provided to identify and prevent errors.

\subsection{Objective of the study}

In this section an overview of the current diesel rebate system in SA and of the challenges associated with the scheme is provided. The previous sections highlighted that the diesel rebate system still has numerous uncertainties and associated challenges. 
This study is aimed at minimising these uncertainties by developing a structured approach to compiling complete and accurate logbooks that would assist in achieving compliance with the law and ensuring that the correct values are being claimed.

This is done by first evaluating the rebates in other countries and then examining more structured South African incentives (such as the Section 12L incentive, which is discussed in section 2.2 below) to assist with the development of the methodology.

\section{LITERATURE}

\subsection{Comparison with other countries}

South Africa is not the only country with a diesel rebate scheme. Similar tax subsidies are offered in other countries, such as New Zealand and Australia [6]. The rebates in these countries are evaluated in order to help minimise the current diesel rebate uncertainties in SA. The aim of this comparison is to evaluate the methods used internationally in order to find similarities and possible solutions. The comparison summary is presented in Table 1Table 1

Table 3: Summary of international diesel rebate schemes

\begin{tabular}{|c|c|c|c|}
\hline $\begin{array}{l}\text { Rebate } \\
\text { requirements }\end{array}$ & South Africa & Australia & New Zealand \\
\hline Type of fuel & Diesel & Diesel, petrol, and fuel oil [18] & Petrol, CNG, LPG [19] \\
\hline Eligible activities & $\begin{array}{l}\text { Off-road vehicles used } \\
\text { for primary production }\end{array}$ & $\begin{array}{l}\text { On-road vehicles greater than } 4.5 \\
\text { tonnes, emergency vehicles, and off- } \\
\text { road vehicles used in primary } \\
\text { activities for primary production }\end{array}$ & $\begin{array}{l}\text { On-road vehicles } \\
\text { greater than } 3.5 \\
\text { tonnes, household use, } \\
\text { and machinery }\end{array}$ \\
\hline Records required & $\begin{array}{l}\text { Diesel usage and storage } \\
\text { logbooks, tax Invoices, } \\
\text { and receipts of diesel } \\
\text { purchases }\end{array}$ & $\begin{array}{l}\text { Type of fuel acquired [20] } \\
\text { Quantity of fuel received }\end{array}$ & $\begin{array}{l}\text { Tax invoice and fuel } \\
\text { summary }\end{array}$ \\
\hline Type of assessment & Self-assessment & Self-assessment & Self-assessment \\
\hline Administration & SARS & Australian Taxation Office (ATO) & $\begin{array}{l}\text { The National Transport } \\
\text { Agency (Waka Kotahi) }\end{array}$ \\
\hline $\begin{array}{l}\text { Quality assurance } \\
\text { and risk } \\
\text { management }\end{array}$ & None & $\begin{array}{l}\text { Claims are risk assessed at the pre- } \\
\text { issue payment stage }\end{array}$ & None \\
\hline $\begin{array}{l}\text { Other governing } \\
\text { bodies }\end{array}$ & None & $\begin{array}{l}\text { Excise Product Committee and } \\
\text { Excise Compliance Committee }\end{array}$ & None \\
\hline Data management & None & None & None \\
\hline
\end{tabular}

Table 3 shows that there are some similarities between the different rebate schemes. One notable similarity is that all of the schemes are based on a self-assessment approach. This means that the claimant is completely liable for the reported data as well as the calculations. One of the concerns noted about New Zealand's scheme is that it is difficult to discover fraud. The current system is therefore unable to distinguish between errors and fraud [19].

In Australia, however, a higher level of support is offered. The ATO, which is responsible for the administration of the rebate scheme, has put risk management strategies in place to address inappropriate or erroneous claims. The ATO seeks to reduce non-compliant claims and errors in two ways: (1) educating taxpayers, and (2) implementing risk assessment and compliance approaches [18]. The ATO has put strategies in place to identify potentially inappropriate claims or significant errors. The ATO conducts preissue payment and post-issue payment integrity checks to manage and identify scheme risks. This protects the tax office by not releasing claims until identified risk payments are deemed appropriate.

The ATO performed a benchmarking study to identify the four most prevalent claim errors. These were:

- clerical errors,

- $\quad$ incorrect calculations from using the wrong fuel scheme claiming rate,

- incorrectly apportioning eligible/ineligible fuel use, and

- claiming for ineligible operations or vehicles.

Although the ATO describes the errors that might occur in diesel claims, there is no step-by-step approach to how a claimant could avoid making similar mistakes. At this juncture, it is noted that $12 \mathrm{~L}$ principles 
might be applicable. The next section investigates the $12 \mathrm{~L}$ data principles from which a stepwise procedure could be developed. The procedure is also aimed at mitigating the errors identified by the ATO.

\subsection{Comparison between diesel rebate and $12 \mathrm{~L}$ incentive}

Section 12L of the South African Income Tax Act (12L) is a government subsidy aimed at incentivising businesses to become more energy-efficient [21]. Similar to the diesel rebate, claiming the 12L tax incentive is a complex and time-consuming process that requires a range of supporting documentation [21], [22]. Strict rules must be adhered to when applying for the $12 \mathrm{~L}$ subsidy [21].

This raises the need to evaluate the regulatory structures of the two incentives. Waldt Hamer [23] has performed an evaluation of the $12 \mathrm{~L}$ regulatory structure. The diesel rebate regulatory structure is evaluated in the same way. Figure 1 presents the comparison between the $12 \mathrm{~L}$ tax incentive and the diesel rebate structure.

\section{$12 \mathrm{~L}$ incentive}

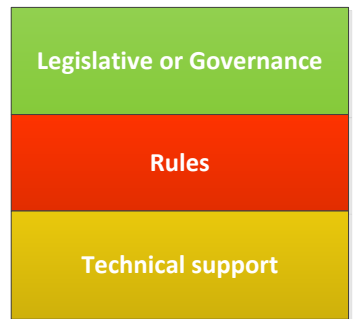

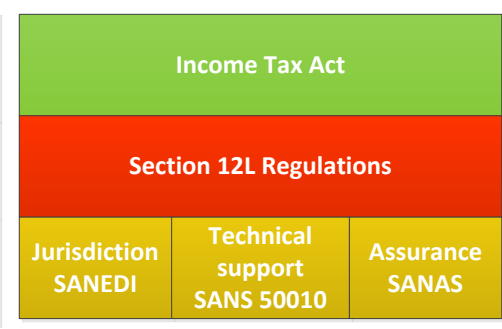

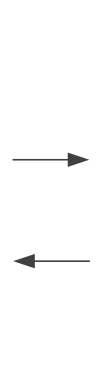

\section{Diesel rebate}

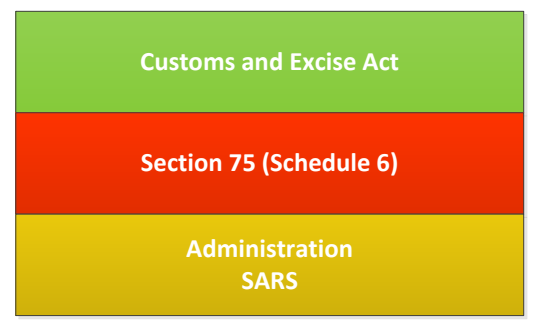

Figure 1: Comparison of the $12 \mathrm{~L}$ regulatory structure and the diesel rebate structure

The main difference between the diesel rebate and the $12 \mathrm{~L}$ subsidy is that the diesel rebate is administered only by SARS and that reported values are based on self-assessment, whereas $12 \mathrm{~L}$ is facilitated by three bodies [16]. The South African National Energy Development Institute (SANEDI) has the responsibility to ensure that the entity claiming the allowance has complied with all the requirements.

SANEDI will only issue a certificate when it is satisfied that the data and information provided can be verified and validated [21]. The SANS 50010 standard provides technical support - i.e., definitions and baseline calculations - while the SANAS-accredited body is used for data verification and assurance [24]. Data quality is fundamental in quantifying and proving energy efficiency for the $12 \mathrm{~L}$ allowance. The three bodies aim to ensure that the claimed allowance is verified and validated. The lack of similar bodies for the diesel rebate claims creates uncertainty for stakeholders.

The lack of a data management structure in the mining sector adds to this uncertainty. To minimise it, and to assist with accurate and trustworthy data, four main data quality issues from the $12 \mathrm{~L}$ tax incentive were evaluated.

\subsection{Data requirements in $12 \mathrm{~L}$ that could be applied to the diesel rebate system}

Data quality evaluation is critical in the $12 \mathrm{~L}$ application process to ensure that accurate and transparent data is used in an application. Four main aspects of data quality were identified from which data-related issues could arise during a $12 \mathrm{~L}$ investigation. These are measurement, verification, traceability, and reporting of data [21].

Data quality is a broad concept with several dimensions. From the literature, a few dimensions were identified that specifically assist with data management and reducing uncertainty in data for energy-related reporting [25], [26]. The dimensions of data quality can be grouped together to address the four data quality issues identified in the 12L application [21]. Table 4 summarises the data-quality dimensions and shows under which issues they can be grouped. 
Table 4: Data quality management [21], [25], [26]

\begin{tabular}{|c|c|}
\hline Data quality dimensions & Main $12 \mathrm{~L}$ data quality issues \\
\hline Accuracy & \multirow{5}{*}{ Data measurement } \\
\hline Objectivity & \\
\hline Believability/ integrity & \\
\hline Reputation & \\
\hline Relevancy & \\
\hline Timeliness & \multirow{3}{*}{ Data verification } \\
\hline Completeness & \\
\hline Amount of data & \\
\hline Accessibility & \multirow{2}{*}{ Data traceability } \\
\hline Access security & \\
\hline Interpretability & \multirow{2}{*}{ Data reporting } \\
\hline Concise representation & \\
\hline
\end{tabular}

Any questionable data will impact the legitimacy of all subsequent calculations and conclusions made from a dataset. Developing an approach that addresses the four data quality issues will ensure accuracy in the data and confidence in the claimable amount. The four data quality issues in Table 4 are used to reduce data uncertainty in the $12 \mathrm{~L}$ process and to ensure an accurate and transparent application. Similarly, the diesel rebate application is also data-intensive, and should be based on the same principles as those of $12 \mathrm{~L}$. Addressing the four main $12 \mathrm{~L}$ data quality issues will result in the respective data quality dimensions being addressed as well.

The next section uses these $12 \mathrm{~L}$ data issues to develop a methodology for the diesel rebate system that will aid accurate data reporting and compliant logbooks.

\section{METHODOLOGY}

The methodology comprises four issues of data quality: data measurement, data verification, data traceability, and data reporting. How the data is measured, processed, used, and verified is a key factor to consider when evaluating data and consequently logbook compliance. Ensuring that these data quality issues are addressed will result in accurate and compliant logbooks.

\subsection{Data measurement}

Data measurement is an essential part of data collection. The first step in data measurement is to identify a measurement boundary [1]. A measurement boundary defines all parameters and variables that need to be measured in order to compile the logbook and to calculate the $\mathrm{E}_{\mathrm{L}}$ value. Second, the most important parameters need to be identified. The quantity of diesel issued, the machine running hours, and the type of machine are the most important parameters for the logbook and the $\mathrm{E}_{\mathrm{L}}$ calculation.

The quantity of diesel issued is important to show how much diesel was issued to the machine; the running hours are used as evidence that the machine did indeed carry out an activity. $E_{L}$ is the sum of diesel usage for all the vehicles that conduct eligible activities. Equation 2 is used to calculate the $\mathrm{E}_{\mathrm{L}}$ value.

$$
\boldsymbol{E}_{L}=\sum \boldsymbol{h r} * \boldsymbol{I}
$$

Here, $h r$ represents the total hours worked by a specific vehicle before the next fill-up, and I represents the intensity of the vehicle in litres per hour. The intensity can be obtained from the machine manufacturer or calculated. The calculation of $I$ is beyond the scope of this article, since it can be obtained from the manufacturer. Equation 3 shows how $h r$ is calculated.

$$
h r=E_{\text {final }}-E_{\text {initial }}
$$

Here, $E_{\text {final }}$ represents the final engine hours of the vehicle before filling up, and $E_{\text {initial }}$ represents the initial running hours of the vehicle when it last filled up. The engine hours must be reported for every transaction.

The third step is to identify how the data is going to be collected or measured. There are two methods of data collection: manual and automated [27]. Both methods can be used, depending on the digital maturity of the organisation. It should be noted that automated data collection is ideal as an approach that will reduce the effort required to review the data, but it might be financially infeasible. 


\subsection{Data verification}

Assurance uncertainties are triggered by possible errors in the data [15]. Verification is essential to ensure that the data is accurate for decision-making by identifying errors in the system [28]. Double entry method and proofreading method are widely known verification techniques [28]. Data verification is dependent on the source of the available data - typically invoices, calibration records, photos, or meter readings. The first step in the verification process is to identify the available source documents, followed by selecting the verification method.

A logbook is compliant if it is complete. The third step is to verify the data's completeness. The total diesel removed from the storage facility - e.g., the tank - must be equal to the sum of all the individual diesel transactions issued to different vehicles. There must be a balance between what left the tank and what was received by a vehicle. Mass balance is a chemical engineering concept used to determine the balance of materials [29].

The concept of steady state mass balances is used to ensure that all diesel issues are accounted for in the logbook. 'Steady state' refers to no accumulation or generation [30]. Mass balance is therefore an effective tool to use to evaluate data, since the balance closure encapsulates the total associated error in the data. A typical mass balance may be represented as shown in Equation 4:

$$
\text { Mass }_{\text {in }}=\text { Mass }_{\text {out }}
$$

A pump meter is installed in all diesel storage tanks to measure the amount of diesel issued. Minimal fouling in the measuring equipment is assumed. The above formula can be expanded for the diesel pumping system as:

$$
\boldsymbol{P}_{\text {final }}-\boldsymbol{P}_{\text {initial }}=\sum \boldsymbol{Q}_{\text {vehicles }}
$$

In Equation 5, $P_{\text {final }}$ equals the final meter reading after diesel has been issued, $P_{\text {initial }}$ equals the pump meter reading before diesel is issued to vehicles for a specified period - i.e., a day, month, or year. $Q_{\text {vehicles }}$ represents the diesel issued to an individual vehicle.

Apart from the quality of the reported data, diesel rebates are dependent on the type of activities carried out by an organisation. A checklist can be developed to verify that the claimable activities are indeed eligible. A check list must include the following:

- $\quad$ Type of diesel usage (farming, mining, offshore, etc.)

- Vehicle type (excavator, dump truck, drill rig, bakkie, etc.)

- Description of activity (ore transportation, drilling, etc.)

- $\quad$ Area where activity is carried out (e.g., on the road, within mining premises)

After the last step of verifying eligible activities, a complete logbook can be generated and the $E_{L}$ value can be quantified. The next step is to ensure that all the data in the logbook can be traced to its source.

\subsection{Data traceability}

Traceability gives a pathway by which data can be attained [15],[23]. Having knowledge of how and from where certain values are obtained provides certainty about the data. Thus, it is necessary for the data not only to be measured correctly and accurately, but also to be moved effectively to the point where it can be retrieved and processed sufficiently.

To ensure logbook compliance for the diesel rebate, a centralised file structure will be developed that includes all the raw data, source documentation, assumptions, calculations, and final claim values. This will ensure that all the data and information is traceable and accessible for verification. Diesel rebate claims may be audited by SARS up to five years after the claim has been made. Having a centralised and traceable file structure that provides the flow of information from its origin to the reported result can be useful for audits and will speed up the process.

\subsection{Data reporting}

Reporting the data is the final step in the methodology. The previous three steps are all used to ensure that accurate, traceable, and compliant information is used. The last step is to ensure that the data and information are reported to SARS in a compliant manner. 
A SARS-preferred logbook is available on the SARS website. The final measured, verified, and traceable data is used to generate a compliant logbook. Once all the aspects of data quality have been adhered to, a final logbook with an accurate $E_{L}$ value can be saved in the centralised folder and the value can be reported to SARS via the VAT system.

\subsection{Summary of the methodology}

The study provides a structured approach to compiling compliant diesel logbooks by addressing four data issues that are prevalent in $12 \mathrm{~L}$ applications. A summary of the developed methodology is provided in Figure 2.
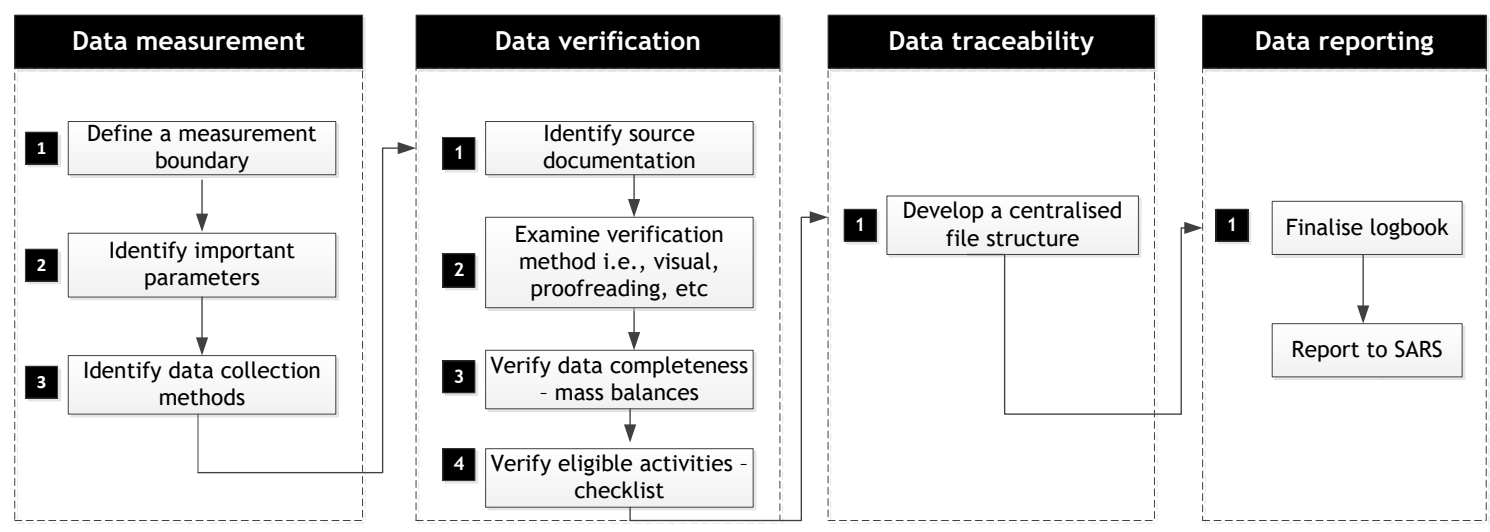

Figure 2: Summary of developed methodology

This process provides a stepwise procedure to ensure that the values submitted to SARS are trustworthy. The methodology is used and validated in Section 4.

\section{RESULTS AND DISCUSSION}

\subsection{Case study background}

The final section of this paper illustrates a practical application of the methodology developed in Section 3. It should be noted that logbooks are typically submitted on a monthly basis. The steps described in Section 3 are applied to a case study for one month's data. The case study is an opencast mine that uses diesel to carry out several mining activities. Roughly 70 per cent of the diesel is used for primary production processes.

\subsubsection{Data measurement}

Data management is characterised by three steps. The steps are followed in the case study and are discussed in detail in this section.

Step 1: Define a measurement boundary

In order to define the measurement boundary completely, a site visit was conducted, from which a process layout was developed showing the diesel distribution from purchase to use. Figure 3 shows the measurement boundary and all of the variables that were measured. The status of the data is also indicated using a colour code.

All but two of the variables are indicated as compliant; and that data is available for the specific period. The two tank levels at B1210 and B5022 have no available data because they are vehicles that transport diesel. However, their level data is not important for the diesel rebate calculations, as both of those vehicles have pump meters. 


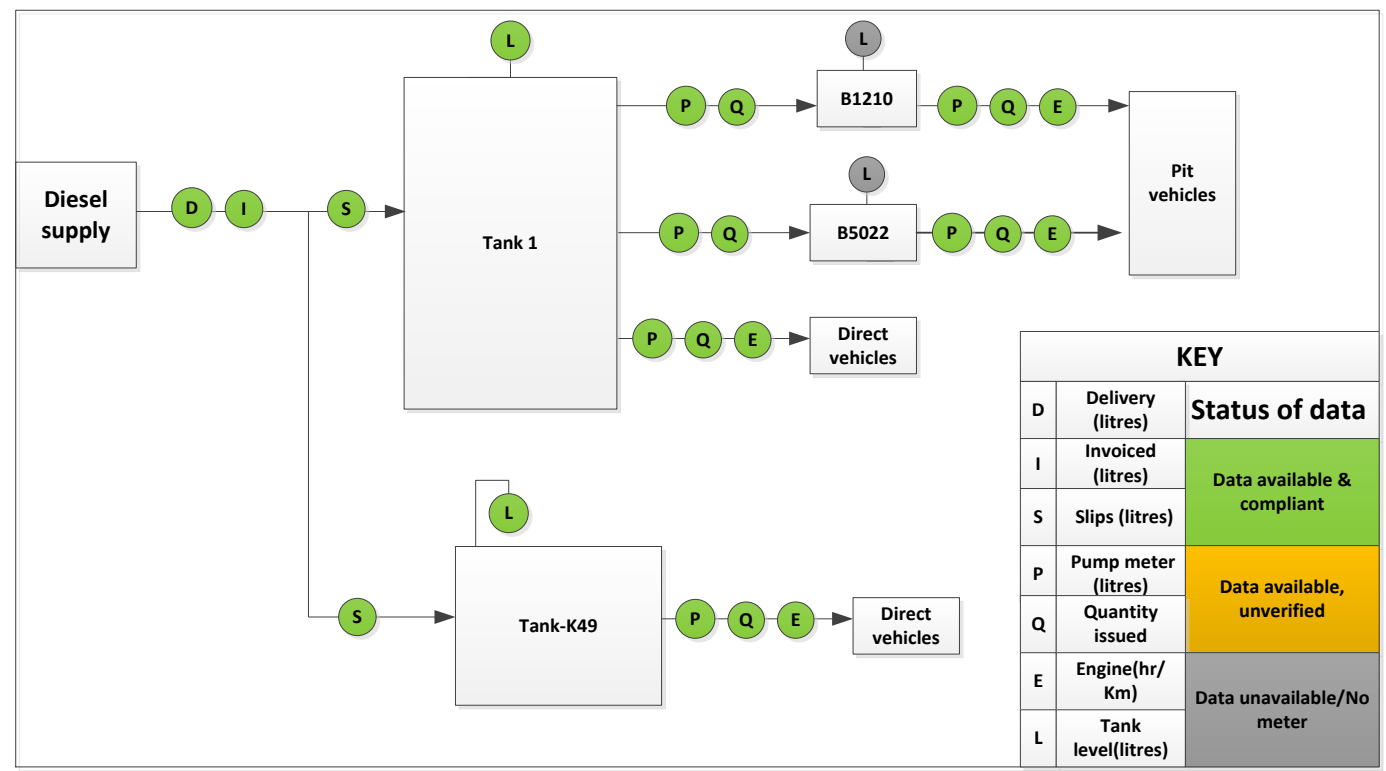

Figure 3: Diesel process layout

Step 2: Identify important parameters

From step 1, all of the parameters in the measurement boundary were identified. SARS makes a logbook template available, in which it is stated that the most important parameters are running hours $(\mathrm{E})$ and the quantity of diesel issued (Q). Vehicle descriptions and the location in which diesel was issued are important. Four locations of diesel storage and issue are present in the measurement boundary: Tank 1, Bowser 5022, Bowser 1210, and Tank-K49.

\section{Step 3: Identify data collection methods}

For this case study a mobile application was developed to collect the data. The development of the mobile application is beyond the scope of this study, and so is not discussed further. However, the application was used alongside handwritten manual logs to collect data. The data that was captured on handwritten sheets and the mobile application together contained the three parameters, and $\mathrm{E}$ and $\mathrm{Q}$ were supported by photos.

For organisations that are unable to access this simple application, a Google Form is an alternative platform that could be applied to capture the information, and only capture images for verification and during audits.

The use of the collected data is evaluated in the next section.

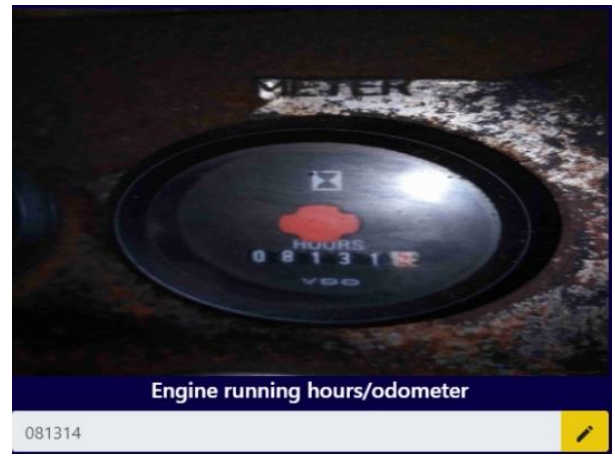

Figure 4: Photo showing running hours $(E)$

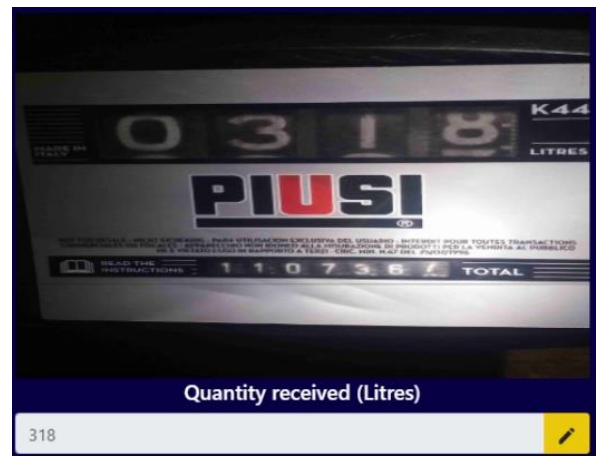

Figure 5: Photo showing quantity issued (Q)

\subsubsection{Data verification}

The steps for data verification are followed in the same way as in Section 4.1.1. Steps 1 and 2 are combined, since the verification technique is dependent on the available source data. 
Steps 1 \& 2: Identify source documentation/select verification method

A source document gives the assurance that the reported figure is indeed true. The data collected by the mobile application is added to a centralised database from which data can be extracted. The benefit of using the application is that it was designed in accordance with 'poka yoke' mechanisms. ('Poka yoke' is a Japanese concept that, translated into English, means 'mistake-proofing' [31]). The aim of this mechanism is to avoid mistakes by those who operate it. The application follows 'poka yoke' by forcing the user to select the correct parameters and to fill in all of the fields before saving the transaction, thus minimising the risk of errors.

The proofreading technique is used to further verify the accuracy of the captured data. Instead of the conventional method of using handwritten data to verify summarised data, the mobile application makes provision for photos, which help to verify the reported $E$ and $Q$ values. A simplified illustration of the process is presented in Figure 6: Data verification processFigure 6.

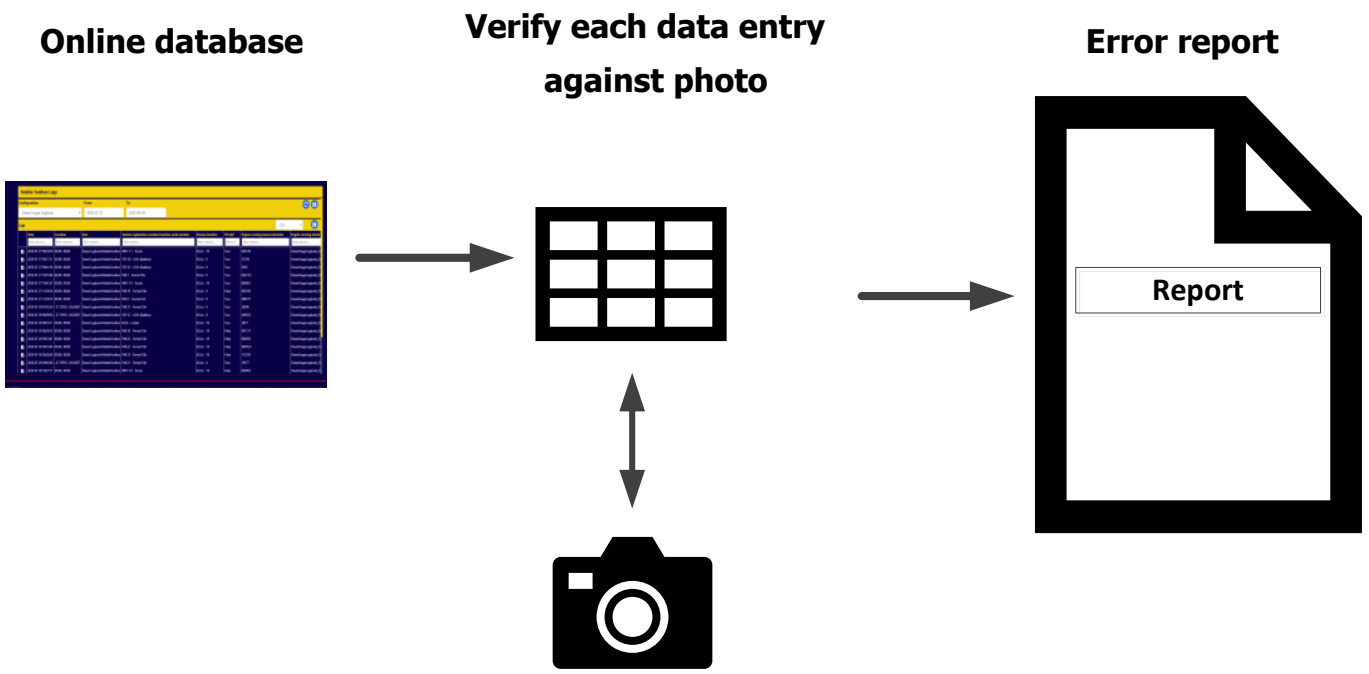

Figure 6: Data verification process

All of the data entries were verified against the photos from the mobile application. A total of 151 errors were identified in the month that was studied. For the engine hours (E) parameter, 86 errors were identified. For the diesel quantity issued $(\mathrm{Q}), 52$ errors were found. Thirteen other errors were attributed to the selection of the incorrect location and vehicle registration. The error report provides a summary of all the errors that are found and prioritises the most important areas. The errors then need to be corrected before the data's completeness can be verified.

\section{Step 3: Verify completeness of data}

To evaluate the data's completeness, Equations 4 and 5 are used (Section 3). The total litres of diesel removed from the storage tank through the pump should be equal to the sum of all the individual diesel issues received by vehicles and machines. The case study has four diesel storage facilities. This means that the mass balances must be carried out on all storage units. Table 5 summarises the results of the monthly balance.

Table 5: Summary of mass balance results for four storage facilities

\begin{tabular}{|c|l|r|r|r|r|}
\hline \multicolumn{7}{|c|}{ MONTHLY BALANCE } \\
\hline Row & \multicolumn{1}{|c|}{ Variable } & \multicolumn{1}{c|}{$($ Tank 1) } & (Bowser 5022) & (Bowser 1210) & (Tank - k49) \\
\hline $\mathbf{1}$ & $\boldsymbol{P}_{\text {initial }}$ & 57618022 & 3379889 & 1664749 & 940901 \\
\hline $\mathbf{2}$ & $\boldsymbol{P}_{\text {final }}$ & 58238349 & 3419416 & 2028300 & 961742 \\
\hline $\mathbf{3}$ & $\boldsymbol{P}_{\text {final }}-\boldsymbol{P}_{\text {initial }}$ & 620327 & 39527 & 363551 & 20840 \\
\hline $\mathbf{4}$ & $\boldsymbol{Q}_{\text {vehicles }}$ & 465053 & 4624 & 205757 & 20841 \\
\hline $\mathbf{5}$ & $\begin{array}{l}\text { Difference } \\
\text { (Row 4 - Row 3) }\end{array}$ & -155274 & -34903 & -157794 & 0 \\
\hline
\end{tabular}

Ideally, the difference between Row 3 and Row 4 should be zero, which would indicate that there were no missing data or diesel transactions. The negative difference in Row 5 is an indication that data is missing 
in the database. The data is therefore not sufficient to compile a logbook as required. The missing data should be sourced and merged into the report to ensure that the logbook is compliant. An investigation was conducted to understand the significant difference seen in row 5. It was found that the operators were in the early stages of adapting to the new system. The device was therefore not properly used, which resulted in the large deviation.

The case study used a mobile application alongside handwritten sheets. The data from these manual sheets was merged into the report and the balance was recalculated. The results after adding the missing data are given in Table 6.

Table 6: Summary of mass balance after merging missing data

\begin{tabular}{|c|l|r|r|r|r|}
\hline \multicolumn{7}{|c|}{ MONTHLY BALANCE } \\
\hline Row & \multicolumn{1}{|c|}{ Variable } & \multicolumn{1}{c|}{ (Tank 1) } & (Bowser 5022) & (Bowser 1210) & (Tank - k49) \\
\hline $\mathbf{1}$ & $\boldsymbol{P}_{\text {initial }}$ & 57618022 & 3379889 & 1664749 & 940901 \\
\hline $\mathbf{2}$ & $\boldsymbol{P}_{\text {final }}$ & 58238349 & 3419416 & 2028300 & 961742 \\
\hline $\mathbf{3}$ & $\boldsymbol{P}_{\text {final }}-\boldsymbol{P}_{\text {initial }}$ & 620327 & 39527 & 363551 & 20840 \\
\hline $\mathbf{4}$ & $\boldsymbol{Q}_{\text {vehicles }}$ & 620340 & 39770 & 363709 & 20841 \\
\hline $\mathbf{5}$ & $\begin{array}{l}\text { Difference } \\
\text { (Row 4 - Row 3) }\end{array}$ & $\mathbf{1 3}$ & $-\mathbf{9}$ & $\mathbf{1 5 8}$ & $\mathbf{0}$ \\
\hline
\end{tabular}

From Table 6 it can be noted that there are some slight differences, but all are within one per cent. These differences can be allocated as general losses to the system. The logbook section also makes provision to report estimated losses. By using mass balances as verification, a complete logbook has been compiled.

\section{Step 4: Verify eligible activities}

It is important to note that the diesel rebate may only be claimed for eligible diesel purchases. There have been court cases for companies incorrectly apportioning eligible and non-eligible diesel use. This step should be conducted alongside Schedule 3 (Part 3) of the Act. The checklist developed in Section 3.3 was used to verify the eligible activities. A shorter version of the checklist, containing five of the 143 vehicles is used for this article. The vehicle type, description of activity, location, and eligibility status are provided in Table 7 for the five registered vehicles.

Table 7: Eligibility checklist

\begin{tabular}{|c|c|l|c|l|c|l|l|}
\hline $\begin{array}{c}\text { Vehicle } \\
\text { registration }\end{array}$ & \multicolumn{2}{|c|}{ Vehicle type } & \multicolumn{2}{|c|}{ Description of activity } & \multicolumn{2}{c|}{ Location } & Eligibility status \\
\hline 1 & $\checkmark$ & Excavator & $\checkmark$ & Load ore & $\checkmark$ & Pit - Off road & Eligible \\
\hline 2 & $\checkmark$ & Dump truck & $\checkmark$ & Transport ore & $\checkmark$ & Pit - Off road & Eligible \\
\hline 3 & $\times$ & Bakkie & $\times$ & Transport labourers & $\times$ & On road & Non-eligible \\
\hline 4 & $\checkmark$ & Dump truck & $\times$ & Transport final product & $\times$ & On road & Non-eligible \\
\hline 5 & $\times$ & Crusher & $\times$ & $\begin{array}{l}\text { Crush ore before } \\
\text { processing }\end{array}$ & $\times$ & Processing plant & Non-eligible \\
\hline
\end{tabular}

Table 7 indicates that only two vehicles are eligible for the diesel rebate application; vehicles 1 and 2 . Dump trucks (vehicle 4) on their own are eligible for a rebate claim, as they are mainly used to transport primary material - that is, ore. However, when they are used for non-eligible activities such as transporting the final product, they are considered non-eligible. Vehicles 3 and 5 are also not eligible, since they do not meet the requirements. Therefore, only the first two vehicles can be used for the rebate quantification process.

\subsubsection{Data traceability}

The next phase is to ensure that the data is accessible and traceable for a possible audit. The final usage and storage logbooks should be saved in a secure folder. SARS requires specific records to substantiate a claim: purchase invoices, diesel logbooks, and all source documents that are available.

\subsubsection{Data reporting}

At this point the logbook has been completed and the $\boldsymbol{E}_{\boldsymbol{L}}$ value has been quantified using Equations 2 and 3. The claimable amount $\boldsymbol{C}_{\boldsymbol{R}}$ is calculated using Equation 1. The amount claimed from this case study amounted to R1.1 million. The same methodology was applied to four other case studies, and the total claim came to more than R5 million. The results are summarised in Table 8. 
Table 8: Summary of the rebate claims

\begin{tabular}{|c|c|c|c|}
\hline Case studies & $\boldsymbol{E}_{\boldsymbol{L}}[\mathrm{L}]$ & $\boldsymbol{R}[\mathrm{R} / \mathrm{L}]$ & $\boldsymbol{C}_{\boldsymbol{R}}(\mathbf{8 0 \%})[\mathrm{R}$ million] \\
\hline 1 & 383607 & 3.49 & $\mathrm{R} 1.07$ \\
\hline 2 & 470909 & 3.49 & $\mathrm{R} 1.31$ \\
\hline 3 & 543294 & 3.49 & $\mathrm{R} 1.52$ \\
\hline 4 & 339814 & 3.49 & $\mathrm{R} 0.95$ \\
\hline 5 & 399771 & 3.49 & $\mathrm{R} 1.10$ \\
\hline Total & $\mathbf{1 7 3 7 6 2 4}$ & & $\mathrm{R} 5.95$ \\
\hline
\end{tabular}

The diesel in the five case studies was used before April 2021, with the previous rate of R3.49 per litre being used in Table 8. The next step is to finalise the logbook and to report to the stakeholders. This is to ensure that all parties are confident about the $E_{L}$ value, the supporting documents, and the reporting structure.

\section{CONCLUSION}

Several uncertainties and challenges associated with the SA diesel rebate scheme were identified. Diesel rebate schemes in other countries were examined, as well as data quality issues associated with the SA 12L incentive. This study provided a structured approach, using four $12 \mathrm{~L}$ data quality issues to ensure that a compliant diesel logbook was generated. The methodology was applied to five case studies, and addressed all of the uncertainties about diesel rebate claims. Stakeholder confidence is important, and it can be ensured with this method, which gives guidance for compiling compliant logbooks in a stepwise manner. Although the logbooks were not audited, the stakeholders had enough information to substantiate a claim of R5.95 million.

\section{REFERENCES}

[1] H. Janse van Rensburg, "Structuring mining data for RSA Section 12L EE tax incentives", M.Eng. dissertation, Dept. Mech. Eng, North-West University, Potchefstroom, 2016.

[2] E. da Cunha Rodovalho, H. Mota Lima, and G. de Tomi, "New approach for reduction of diesel consumption by comparing different mining haulage configurations", Journal of Environmental Management, vol. 172, pp. 177185, February 2016.

[3] Department of Resources, Energy and Tourism, "Analyses of diesel use for mine haul and transport operations", Case study, Australia, 2008. [Online]. Available:

https://www.energy.gov.au/sites/default/files/analyses_of_diesel_use_for_mine_haul_and_transport_operation s.pdf [accessed 14/03/21]

[4] P. Perold, "New technological level gold mining applications in new technological applications in deep-level gold mining", DMR, Pretoria, pp.1-20, 2013. [Online]. Available:

https: / / www.dmr.gov.za/LinkClick.aspx?fileticket=CIEuCiHYXLA\%3D\&portalid=0 [accessed 10/03/21]

[5] Minister of Finance, "Budget speech", pp. 1-19, February, 2001.[Online]. Available:

http://www.treasury.gov.za/documents/national\%20budget/2001/speech/speech.pdf [accessed 15/04/21]

[6] National Treasury, "Discussion paper for public comment: Review of the diesel fuel tax refund system", February, 2017. [Online]. Available:

http://www.treasury.gov.za/comm_media/press/2017/20170215001\%200review\%20of\%20the\%20diesel\%20fuel\%2 0tax\%20refund.pdf [accessed 22/01/21]

[7] Republic of South Africa, "Customs and Excise Act 91 of 1964", January 1965.

[8] Republic of South Africa, "Schedule 6 Customs \& Excise Tariff", no. 6, April, 2019.

[9] South Africa Revenue Service, "manage diesel refund calculations", no.1 April, pp. 1-6, 2020.[Online]. Available: https://www.sars.gov.za/wp-content/uploads/Ops/Policies/SE-DSL-02-Manage-Diesel-Refund-CalculationsExternal-Policy.pdf [Accessed 05/01/21]

[10] T. Ncanywa and N. Mgwangqa, "The impact of a fuel levy on economic growth in South Africa", Journal of Energy in Southern Africa, vol. 29, no. 1, pp. 41-49, 2018.

[11] D. J. Marais, “'Must-know' information surrounding SARS' diesel rebates”, Africlock, pp. 1-8, May 2016.[Online]. Available:

https://www.africlock.co.za/wp-content/uploads/2012/05/Diesel_Rebate_must_know_final_May2016.pdf [accessed 15/10/2020]

[12] Agri SA and South African Institute of Tax Professionals, "Diesel refund survey", 2018. [Online]. Available: https://cdn.ymaws.com/www.thesait.org.za/resource/resmgr/2018_newsletter_links/AgriSA_2018_diesel_refun d_su.pdf [accessed 20/10/2020]

[13] U. Diale-ale, "Diesel rebate cases in the high court have implications for mining operations", Without Prejudice, vol. 21 pp. 18-19, April, 2020. [Online]. Available: https: / /journals.co.za/doi/10.10520/EJC-1c596c7f6c [accessed 20/11/21]

[14] M. van Heerden, "Environmental data management for gold mines", PhD thesis, Dept. Industrial. Eng., North-West University, Potchefstroom, 2017. 
[15] A. G. S. Gous, W. Booysen, and E. H. Mathews, "Assurance framework for South African carbon tax", in $201829^{\text {th }}$ Annual Conference of South African Institute of Industrial Engineers (SAIIE), Stellenbosch, 2018.

[16] A. G. S. Gous, W. Booysen, and E. H. Mathews, "Addressing uncertainties in the South African Carbon Tax landscape", in 2017 International Conference on the Industrial and Commercial Use of Energy (ICUE), Cape Town, 2017.

[17] SARS, “Diesel usage logbook", Draft, 2013. [Online]. Available: https://www.sars.gov.za/wpcontent/uploads/Legal/Drafts/LAPD-LPrep-Draft-2013-17-Draft-Tariff-Amendment-Diesel-Usage-Logbook.pdf [accessed 13/10/20]

[18] Australian National Audit Office, "Fuel tax credits scheme", Australia, Audit report no. 49, 2010. [Online]. Available: https://www.anao.gov.au/work/performance-audit/fuel-tax-credits-scheme [accessed 18/02/21]

[19] Ministry of Transport, "Fuel excise duty refund and regional fuel tax rebate entitlements", New Zealand Government, pp. 1-18, March 2020. [Online]. Available:

https: / /www.transport.govt.nz/assets/Uploads/Report/FED-refund-and-RFT-final-report.pdf[accessed 18/02/21]

[20] Australian Taxation Office, "Fuel tax credits", August 2014. [Online]. Available: https://www.ato.gov.au/uploadedFiles/Content/ITX/downloads/BUS18867_n15621.pdf [accessed 19/02/21].

[21] K. Campbell, W. Booysen and J. C. Vosloo, "Evaluating the feasibility of the 12L tax incentive for energy-intensive industries", South African Journal of Industrial Engineering, vol. 28, no.3, pp. 15-28, November 2017.

[22] K. Steyn, “Section 12L tax allowance: Why the delay?", 2015. [Online].Available: http://www.ee.co.za/article/section-12l-tax-allowance-delay.html [accessed 15/03/21].

[23] W. Hamer, "A practical approach to quantify RSA Section 12L EE tax incentives for large industry", PhD thesis, Dept. Mech. Eng., North-West University, Potchefstroom, 2016.

[24] W. Hamer, W. Booysen and E. H. Mathews, "A practical approach to managing uncertainty in the measurement and verification of energy efficiency savings", South African Journal of Industrial Engineering, vol. 28, no. 3, pp. 128-146, November 2017.

[25] D. Henderson, S. Earley, and L. Sebastian-Coleman, "Data quality", in Data management body of knowledge, $2^{\text {nd }}$ ed. Technics Publications, 2017, pp. 454-456.

[26] J. Booysen, "Application of accounting principles on energy-related reporting", PhD thesis, Dept. Mech. Eng., North-West University, Potchefstroom, 2020.

[27] M. D. Byrne, T. R. Jordan and T. Welle, "Comparison of manual versus automated data collection method for an evidence-based nursing practice study", Applied Clinical Informatics, vol.4, no.1, pp. 61-74, 2013.

[28] S. R. Ngwaku, "A strategy for potable water conservation in gold mines", MEng. dissertation, Dept. Development and Management Eng., North-West University, Potchefstroom, 2020.

[29] I. Rinard, “Material balance notes", Dept. Chem. Eng., City College of CUNY and Project ECSEL [Online]. Available: http://www.feq.unicamp.br/images/stories/documentos/eq481_apostila_bmassa.pdf [accessed 24/04/21].

[30] R. Levicky, “Material balance”, Dept. Chem. Eng., Polytechnic University, pp. 20-29. [Online]. Available: https://www.studocu.com/en-gb/document/university-of-nottingham/atmospheric-chemistry/notes-adescription/4353391 [accessed 21/06/21]

[31] I. D. Tommelein, “'Poka yoke' or quality by mistake proofing design and construction systems”, in 16th Annual Conference of the International Group for Lean Construction, pp. 195-205, 2006. 